journal will stand the test of comparison with any of its contemporaries, and the immediate promise of a series of papers on the anatomy and embryology of Amia augurs well for its future.

Prof. Cope contributes a very characteristic paper on the tritubercular molar, the leading deduction of which is most interesting and suggestive; it reads (vol. ii. p. 2 r): "The tritubercular molars of man constitute a reversion to the dentition of the Lemuridæ of the Eocene period of the family of Anaptomorphidæ," and "this reversion is principally seen among the Esquimaux, and the Slavic, French, and American branches of the European race." The senior editor, discussing, in the most philosophic paper of the series, "The Seat of Formative and Regenerative Energy," writes as follows: "These higher (biological) units combine both atomic and molecular structure, but they have, superadded to and including this, a structure as a whole, which is entirely ignored in the expression, ' molecular aggregates.' As they result from the union, not of simple or complex molecules, but of complex molecular sroups, their structure may be said to be at least as widely separated from the molecule as this is from the atom"; and, further, "in claiming that "physiological units' have something higher than molecular structure and power, I am not treading on ultra-scientific ground, but following the course already sanctioned by chemistry and physics, and the only one which can ever reconcile physico-chemical and biological conceptions." We heartily recommend this valuable essay to our readers, for the author's contentions in defence of his belief that "the organism as a whole controls the formative processes going on in each part," are worthy of all the consideration that can be given them. He appears to us to underestimate the importance of recent advance in organic chemistry. The work of unravelling the constitution of the more complex organic bodies-a work in which certain of our own countrymen are playing a leading part -gives us hope beyond that which he entertains. The presence of the above-cited remarkable passiges is, in itself, sufficient to invest the early numbers of this journal with a lasting interest.

We congratulate the editors upon their enterprise they are supported by influential friends and surrounded by enthusiastic investigators ; they have, in turn, fulfilled, thus far, the highest expectations of their most sincere well-wishers, and merited the confidence and support of the biological brotherhood throughout the world.

G. B. H.

\section{THE BALD-HEADED CHIMPANZEE.}

$\mathrm{T}$

ERE is no longer any room for doubt amongst larger anthropoid ape of the complete distinctness of the its smaller brother, the chimpanzee. The differences are amply sufficient for specific, if not for generic, distinction. But, on the question whether there is only one chimpanzee, spread over a great extent of the African continent, or several species confounded under the same name, there is still much difference of opinion. As long ago as I 853, M. Duverroy communicated to the Academy of Sciences of Paris a short description of a second species of chimpanzee (see Comptes rendus, vol. xxxvi. p. 927), based on specimens obtained by Dr. Franquet in Gaboon in $185 \mathrm{I}$. M. Duvernoy subsequently published an elaborate memoir on the same subject in the Archives du Musúum (vol. viii. p I). The distinctions insisted upon by Duvernoy between his Troglodytes tschego and the ordinary $T$. niger were chiefly osteological; at the same time he characterized the tschego (from M. Franquet's description) as having the "face black, and the ears small," while, according to the same authority, the ordinary chimpanzee has "very large ears, and its face flesh-coloured."
In 1858 , in a memoir also published in the Archizes du Muséum (vol. x. p. 94), on the specimens of anthropoid apes in the Paris collection, M. Isidore Geoffroy St. Hilaire published a letter from Dr. Franquet in which the latter again insisted on the differences of the three species of anthropoid apes observed by him in the district of Gaboon. These were characterized as follows:-

(1) The Chimpanzee, with the face flesh-coloured, the ears red and large, and the fur black.

(2) The Gorilla, with the face black, the ears small and black, and the fur of a brownish chestnut, but varying in tint in different parts of the body, and with always a row of reddish hair starting from the middle of the forehead and following the line of the sagittal suture.

(3) The N'tchego, with the face black and the ears small, as in the gorilla. The hairs of this ape, he says, are shorter and darker in colour, and it never attains the size of the gorilla, or carries the red crest across the forehead.

In I 860, the well-known traveller Mr. P. B. Du Chaillu gave his account of the anthropoid apes of the Gaboon to the Boston Society of Natural History (see Proceedings of that Society, vol. vii. p. 296). Mr. Du Chaillu described, as a new species of chimpanzee, Troglodytes calvus, "with the head entirely bald to the level of the middle of the ears behind," and " having large ears," while he identified the N'tchego of Dr. Franquet as being nothing but the adult chimpanzee (T.niger). In a second communication to the same Society (op. cit. p. 358), he described another new species of chimpanzee, with a black face, but the forehead not bald, which he called Troglodytes kooloo-kamba, from its peculiar cry.

In I86I, the late Dr. J. E. Gray examined Mr. Du Chaillu's specimens of apes, and came to the conclusion that both his supposed new species werc only varieties of the common chimpanzee (see P.Z.S., I861, p. 273). Such also, as was stated by Dr. Gray, was my own opinion at that time, and I have remained in a doubtful state of mind on the subject until a recent period. But the acquisition of the fine female specimen of chimpanzee, generally known by the name of "Sally," by the Zoological Society in 1883 , caused me to change my views very materially. There can be no doubt that this animal, when compared with specimens of the ordinary chimpanzee, presents very essential points of distinction. The uniform black face and nearly naked forehead, which is only covered with very short black hairs, together with the large size of the ears, render "Sally " conspicuously different from the many specimens of the common chimpanzee (at least thirty in number) that the Society has previously received. I was at first inclined to believe that "Sally" might be referable to the Troglodytes tschego of Duvernoy. But nothing is said, in M. Duvernoy's description, of the bald forehead; and the small ears attributed to the N'tchego, are directly contrary to this hypothesis, as in "Sally" these organs are exceedingly large and prominent. On the whole, I was inclined to believe that "Sally" mirht belong to the Troglodytes calvus of Du Chaillu, and she was accordingly entered in the Register of the Society's Menagerie as the Bald-headed Chimpanzee (Anthropopithecus calous ${ }^{1}$ ), which is certainly a very appropriate name, even if it be not technically correct.

In the beginning of December we purchased of $\mathrm{Mr}$. Cross, of Liverpool (from whom we had also obtained "Sally"), a second specimen of the Bald-headed Chimpanzee, likewise a female, which, although much smaller in size, closely resembles "Sally" in every other respect.

Fortunately, there is now in the Gardens a young specimen of the Common Chimpanzee (Anthropopithecus troglodytes), presented to the Society in May last by

The term Troglodytes being more properly used for a genus of birds, it bec rmes necessary to employ for the chimpanzess the generic term "Anthropopithecus," of Blainville, as suggested by Peters in 1876 
Mr. F. J. Aldridge, F..S.. by whom it was brought from Sierra Leone. This sperimen is of about the same size and agre as the young Bald headed Chimpanzee, and enables an easy comparison to be made between the two species. Looking first at $A$. calius, we find the skin of the head, face, ears, and limbs of a dark brownish clay colour, which will, no doubt, get blacker as the animal becomes adult. The ears are perfectly naked, and of large size, and stand out at ncarly richt angles from the head. The top of the head is very scantily covered with short blackish hair. The whole of the body and limbs are also very thinly covered with hair, especially the abdomen.

When we turn to the young specimen of A.troglodytes, we find the upper part of the face and the brows of a dirty flesh colour. Between the eves, above the nostrils, and passing down the cheeks, it is black. The nose and muzzle are of a dirty flesh colour. The chin and upper lip are covered with longish white hair. The inside of the ears is nearly black. The foreheat, cheeks, and the whole of the body are covered with long, harsh, black hair. The colour of the hands and fect are of a brownish clay colour, much the same as those of $A$. callous.

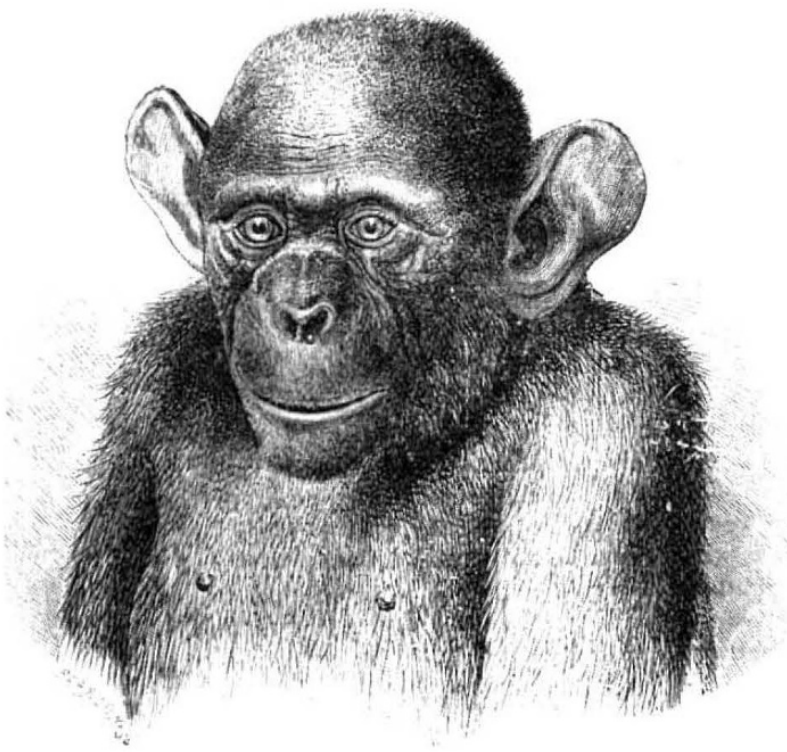

The rump above and below the anus is covered with longish white hair.

With regard to the size of these $1 w 0$ animals, the length of limbs, and other measurements, they are nearly equal It is probible that $A$. troglody'te's is a trifle older than the new specimen of $A$. cillitus.

It may be of interest to mention that, as Mr. Bartlett informs me, the young $A$. culins will kill and eat sparrows in the same manner as "Sally" kills and eats pigeons, whereas the common chimpanzee will not touch any food of this kind.

It must be admitted, however, that the specific term calius, applied to "Sally" and her "younger sister," can only be considered as provisional. When these specimens die, which, we trust, will not be till some distant period, they must be compared with the example of the Troselodyte's calines of Du Chaillu, which is now in the British .Iuseum. On the same occasion the skulls of these specimens can be compared with the descriptions and figures given by I) uvernoy of his Trerlodytes tsihere. lintil this can be done, it is impossible to say decisively whether these two specimens belong to one of the stipposed species already described, or should receive a new name.
Finally, I may add that the Ape House in the Society's (iardens, besides these two chimpanzees, contains at the present time a young female Orang (Simia sutyrus), received on deposit, and a specimen of the Silvery (jibbon (IIylobutes leucisius), lately presented by Captain 1). I.. I elacherois; so that all the three known gencra of anthropoid apes may be now seen represented by living specimens.

P. L.. S.

\section{NOTES}

$A$ Movemr.x has been started in Norway for the despatch in the summer of 1890 of an Fxpedition which would try to reach the North Pule, and it is proposed that the leadership shall be offered to I)r. Nansen. Those who are arranering the plans maintain that no other country could furnish such a crew of experienced and hardy ice men and Arctic travellers as Norway, and that a winter or two in the Arctic regions would affect these men very little. The intention is that an attempt shall be made to reach the Pole by way of Franz. Josef's Land, a route arlvocated by the most experienced Norwegrian Arctic travellers as well as by several well-known men of science who have studied the problem. Ski, which have played such a prominent part in the Nordenskiiidi and Nansen (ireenland expedition;, would no doubt again be of great service.

THE Royal Acatemy of Siciences of Turin, in accordance with the last wiil and testament of Dr. Cesare Alessandro Bressa, and in conformity with the programme pulsished on 1).cember 7 , I $\delta 76$, announces that the term for competition for scientific works and discoveries made in the years $18 S_{5}-8 \delta$, to which only Italian authors and inventors were entitled, was closed on December $3 \mathbf{I}, \mathbf{1 8 8 8}$. The Acalemy now gives notice that from January $I, 1887$, the new term for competition for the seventh Bressa Prize has begun, to which, according to the testator's will, scientific men and inventors of all nations will be adritted. A prize will therefore be given to the scientific author or in. velitor, whatever be his nationality, who during the years 1887.90 , aceurding to the judgment of the Royal Academy of sciences of Turin, shall have made the most important and useful discovery, or published the most valuable work on any of the following subjects-physical and experimental science, natural history, mathematics, chemistry, physiology, pathology, geology, histury, geography, and statistics. The tcrm will be closed at the ent of Ilecember 1990 . The value of the prize amounts to 12,000 Ita'ian lire. The prize will in no case be given to any of the national members of the Acadeny of Turin, resident or non-resident.

THE Board of Electors to the Linacre Professorship of Human and (omprative Anatomy at Oxford have, on accunt of P'rof. Moseley's continued illness, nominated Mr. IV. Hatchett Jackson, M.A., F.I..S., to serve as Deputy Professor.

SIR IIEXRY RUSCoE has been elected to represent the Royal Society on the governing body of Eton College.

WE regret to announce the death of Mrs. Merrifich, whose name as a writer on Algæe and kindred subjects is well known to our readers. She clied on January 4 , in her eighty.fifth year. Iu-clay we print an article by Mrs. Merrifield on some recent works on Algre. We learn that she was very ill when this article was written, but it was not thought that the end was so) near.

IHE annual general meeting of the Royal Meteorological Society will be held at 25 Creat Gerrose Street, Westmirster, on Wednesday, the $16 \mathrm{~h}$ ins:ant, at $7.15 \mathrm{p} . \mathrm{m}$., when the report of the Council will be read, the election of officers and Coincil for the ensuing year will anke place, and the Presitlent (I)r. W. Marcet, F.R.S.) "ill diver an address on "Fugs," which will be illustrated by a number of lantern slides. 